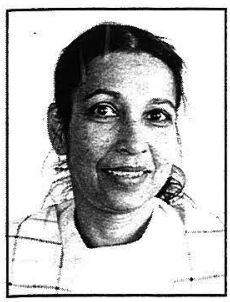

\section{THE PARTNERSHIP APPROACH TO LOCAL EMPLOYMENT GENERATION: SELECTED URBAN INITIATIVES IN NEW ZEALAND}

\author{
Anne de Bruin \\ Massey University, Auckland \\ Grant Power \\ Work and Income NZ
}

\begin{abstract}
Local initiatives for employment creation are vital to the mitigation of high unemployment levels of Maori and Pacific Group people in New Zealand. In order that local communities be empowered to determine their own outcomes, however, government, both local and central, private business and community partnerships working to common agendas, are increasingly being seen as a step in the right direction. This paper examines the extent to which the partnership approach to employment creation operates in some labour market disadvantaged urban communities. It details some of the current projects in operation and comments on their progress. It asks if there are common elements which assist the success of such initiatives.
\end{abstract}

Keywords: employment creation, partnership, urban, Maori, culture

From the mid 1980's, the rapid and dramatic program of economic reform and deregulation, public sector reform and privatisation, the effects of disinflationary domestic policies, followed by a downturn in the international economy, saw unemployment in New Zealand soar, peaking in the early 1990's. 1993 nevertheless, was a dividing line. It marked the beginning of strong employment growth and a significant decline in unemployment. In the September 1996 quarter, the national seasonally adjusted unemployment rate was down to $6.3 \%$. Significant differences between Pakeha/European rates of unemployment and those of Maori and the Pacific Group nevertheless remained. For the September 1996 quarter, the Pakeha rate of unemployment was $4.5 \%$, compared with the Maori rate of $15.9 \%$ and the Pacific Island rate of $14.3 \%$. Over the year to September 1996, only the Pakeha group experienced statistically significant growth in employment (Statistics New Zealand, Household Labour Force Survey, HLFS). 'The process of economic growth could not be relied on to move sufficient numbers of ethnic minority people into employment.

More recently as the overall level of unemployment has begun to move upward, to $7.7 \%$ in the September 1998 quarter, with a slowing of economic growth on account of the unfavourable international climate, the Pakeha rate of unemployment has climbed to $5.4 \%$ while the Maori and Pacific Group rates are $17.8 \%$ and $15.4 \%$ respectively (Statistics New Zealand, HLFS) ${ }^{2}$. Unemployment rates, however, are an imperfect indicator of labour market disadvantage. Labour force participation rates are also of relevance. In the September 1998 quarter, the participation rates of Maori and Pacific Island people had fallen to $60 \%$ and $61.4 \%$ respectively, compared to the European rate of
66.4\%. Analysis of the dynamics of unemployment reveals added labour market disadvantage with Maori and Pacific Group people expected to spend around $22 \%$ longer on the unemployment register and more likely to experience repeated spells of unemployment than other unemployed workers (Mare 1995: 121). Active labour market policies to mitigate disparities in ethnic employment outcomes are therefore well justified.

The changes in New Zealand's manufacturing sector, where employment of Maori and Pacific Island people has been traditionally concentrated, the decline in unskilled job opportunities and the generally lower demand for unskilled labour which parallels the trend in other developed economies, have been important contributory factors for the steep decline in employment levels of these people. While policies which seek to enhance human capital so that these ethnic minorities are able to secure employment in higher skill job generating sectors, are an obvious choice, these policies must, however, be supplemented, especially in the shorter term, by local initiatives for employment creation and lower level skill training and capacity building of the individual. Special locality based efforts become necessary especially in communities where the majority of individuals lack human capital in the form of formal educational qualifications and skills which are compatible with the new technology style of the current phase of capitalism (de Bruin 1998b).

This paper examines the experience of eight local urban initiatives that enhance employment opportunities at the community level. Initiatives that are indirectly responsible for employment generation, for example job brokering and placement and building of 'life skills', are also covered. 
This paper seeks to give information on the types of jobs that are currently being created at the grassroots level and attempts to draw-out any features that are common across such initiatives. It provides illustrations of the partnership approach in action.

The concept of 'partnership' as it relates to this paper, involves an initiative where a local community organisation is a key player at its conception, initiation and development, with this organisation receiving support which can take the form of financial, facilitation, advisory or networking support, from a government organisation (local or central) and/or a private sector organisation. Control and management of the project remains vested with the community organisation, though often circumscribed within the parameters of a contractual relationship of the supporting partner.

Central government support of local employment initiatives and programmes today largely involves the activities of the Community Employment Group (CEG), previously of the Department of Labour and now part of the newly formed agency, Work and Income New Zealand (WINZ) . ${ }^{3}$ Involvement in community based employment initiatives in New Zealand is thus in keeping with the general trend evidenced in other OECD economies where, "the role of central government with regard to employment shifted to enabling and co-ordinating these activities, rather than initiating and delivering them. Regional and local offices of national employment services were given greater flexibility to respond to local needs, and were encouraged to enter into partnership with other actors involved in job creation" (OECD 1993:7).

During the 1990's, as the contracting culture has spread to a greater or lesser extent among local government bodies and especially with the disestablishment of Works Departments by some Councils, local government support of community initiatives has come to be increasingly associated with the securing of contracts for the provision of services previously directly supplied by local government employees. This aspect of the partnership process, therefore, is highlighted in some of the initiatives examined.

\section{The Otara Creek Project}

The Otara Creek Project is an example of a community driven venture which supplies jobs which the market would not have otherwise created for the people of the severely labour market disadvantaged community of Otara ${ }^{4}$. The Creek is a major natural feature, heritage and educational resource of the Otara community. The Creek Project is an initiative of Enterprise Otara (EO), an incorporated society, established to manage change in Otara. Although working toward self sustainability, EO is an organisation largely reliant on Manukau City Council (MCC) and CEG funding for its existence. ${ }^{\mathrm{s}}$

In 1994, EO identified the Otara Creek and Lake as providing significant opportunities to enhance Otara's environmental quality and achieve community, economic, and ecological benefits. Restoration and improving the visual appearance of the creek, greater 'care and ownership' of the local environment and re-establishing the educational value of the Creek were among the community benefits envisaged. Opportunities for local employment were part of the economic benefits, and ecological benefits included enhanced water quality and natural habitats for various birds, fish, animal and plant species. EO, funded by CEG and the Lottery Grants Board, embarked on its Otara Creek Project in 1995. The project, then known as 'Otara Greenprint', would sustain and enhance Otara's own Natural Heritage, through a co-ordinated approach involving the revegetation and conservation of the Creek. The project funding was chiefly used for a full-time worker to research, design and develop a Greenprint Strategic Action Plan, with an ultimate objective being the provision of further employment opportunities. A consultant from Otara, who at the time was an undergraduate engineering student at UNITEC and would also use the project as a supervised internal research project, was employed by EO to work toward the plan. The project provided further immediate educational value with the seventh form students from Hillary College, a local secondary school, helping to assess specific ecological areas for study along the creek margin. In February 1996, a Draft Plan, was completed. The report identified the clean-up and re-vegetation of the creek and creek margin, as Stage One of an action plan (Manu 1996). Following the Report, however, EO's Creek Project remained dormant for over two years. The Otara Creek continued to be the most polluted stream in the Auckland Region (MCC 1998: 99).

The project was rejuvenated, mid 1998 . This was largely through the action and leadership of the new Chairperson of EO, Jim Sinclair. Working initially through, and onward from the Otara Community Board, which allocated funds toward the clean-up of the creek, Sinclair was instrumental in the signing of an Interim Agreement between the MCC and EO in July 1998. This agreement contracted EO for a clean-up of a segment of the creek and the conduct of a community awareness programme targeted at the surrounding residences in the clean-up area. Upon satisfactory delivery of the contracted outputs by EO, the scope of the project area was subsequently extended, so that funding has been assured for a minimum project life of 6 months. The project provides employment for 11 people. One of these is the Supervisor who is a full-time employee and the others are Community Taskforce (CTF) workers. ${ }^{6}$

Although on the surface this project currently appears to be of small consequence in terms of sustainable job creation, the significance and potential of the project runs much deeper. It has been of value as a skill and confidence builder for the workers. They have successfully undertaken a Manukau Institute of Technology (MIT) training course covering the Resource Management Act, Occupation Health and Safety requirements, noxious weed and native plant identification, noxious weed management and eradication, ground preparation and planting of native species. With MIT, the local polytechnic, providing this specially tailored course at no charge, the spirit of community partnership has been strengthened. Direct association with such a project 
also imbues workers with a sense of appreciation and value of their local natural resources. The community awareness programme which is part of the project, should help avoid dumping of rubbish into the creek and general care of the environment. School education programmes involving the creek are also envisaged. Moreover, the smooth running of the project has resulted in the creation of goodwill with MCC personnel involved and increased the credibility of $\mathrm{EO}$ as a contracting organisation to local government and as a community work provider for central government. It has raised the profile of EO in the community, which augurs well for future community employment creation by the organisation. Extension of the project beyond its current 6 month funding life is well on track.

\section{The 2nd Time Recovery Park}

The recycling and reselling of non-organic rubbish is the business of the 2 nd Time Recovery Park, a community enterprise in Papatoetoe in Manukau City. The project initially employed 17 CTF participants, drawn chiefly from the long-term unemployed. Some of these have now become paid workers for the Park. Participants have been trained in the basics of the salvage and recycling by 'experts' from the successful Australian community recycling enterprise, Revolve (CEG 1998a). The Park has received support from the Tindall Foundation and is also supported by CEG through its community broker organisation (CBO), ? the Manukau Urban Maori Authority (MUMA). The enterprise thus is an excellent example of the partnership approach to employment generation with input from both the government (CTF and CEG) and private sectors.

The Park is managed by the Nga Whare Waatea Marae, which is the marae of MUMA. MUMA is one of two urban Maori authorities in the Auckland metropolitan area. It is currently the chief provider of community work programmes for WINZ in the South Auckland region. MUMA has several community projects and established businesses, including a finance company which lends money to set up businesses and Whanau Finance which lends up to $\$ 200$ to CTF workers. Whanau Finance has fellow project participants decide whether their workmate needs to borrow and how much, and then stand guarantor for the borrowed funds.

The chief executive of MUMA, June Jackson, has been the driving force behind the Authority's success. She has been with the organisation since its inception in 1985. Despite some difficult times, especially after cuts in government funding in 1992 and the more recent loss of five key personnel, Jackson's organisational and leadership skills have been at the forefront in MUMA's ability to make a vital difference to employment and other social outcomes of urban Maori in the area. Interestingly, almost $90 \%$ of MUMA's staff are women (Carroll 1998).

\section{Porirua Wastebusters}

Rima Tekau Roopu is an incorporated society that has established a successful recycling business enterprise, Porirua Wastebusters, with the assistance of the Porirua Business Development Society, whose main benefactor is CEG. As with the 2nd Time Recovery Park project discussed earlier, CEG and the Tindall Foundation have also provided funding to the enterprise. The venture was successful in tendering for the Porirua City Council contract to manage the City's transfer stations and recycling depots. This contract has now been secured for a further 12 months. Wastebusters clears the product brought for recycling to the stations and depots, sorts out and stockpiles for ultimate disposal to a variety of reprocessors.

The closure of sunset manufacturing industry plants such as the Mitsubishi car assembly factory, has meant a loss of job opportunities for Maori and Pacific Island people living in lower income communities of Porirua City like Porirua East and Cannons Creek. The Wastebusters initiative provides training and employment opportunities for long-term unemployed residents in these areas. The project itself is driven by a group of four men living in Cannons Creek. Jason Ryder is a key player in this group. Six CTF participants are engaged in the venture at any one time in addition to the three principals. A total of 18 CTF participants have been involved with the venture since its inception through to February 1998. Participation has provided experience for four of them to move to full-time employment.

\section{Hoani Waititi Marae/Te Whanau o Waipareira}

Hoani Waititi Marae is located in Oratia, Waitakere City. It acts as a base for a wide range of community based initiatives. Many of the programmes and projects based at the marae have been undertaken in partnership with $\mathrm{Te}$ Whanau O Waipareira. Waipareira is the urban Maori authority (the other in South Auckland, MUMA, was referred to earlier), active in the communities of West Auckland for over twenty years. This paper reviews three projects which the marae supports: Te Whare Tu Taua O Aotearoa, Whare Wananga and a specialised pre-employment training programme.

Te Whare Tu Taua O Aotearoa (National School of Maori Weaponry) began in 1983. The primary objective of the organisation is to motivate Maori towards success in all aspects of their lives, with a particular emphasis on education. Te Whare Tu Taua uses mau rakau (knowledge of Maori martial arts) as a medium for empowering Maori youth.

The first major public demonstration of the work of $\mathrm{Te}$ Whare Tu Taua came in 1990 when a display of the use of the taiaha (traditional Maori weapon in the form of a staff) by 100 Maori men was incorporated in the opening ceremony of the Commonwealth Games, in Auckland. To date the organisation has visited over 100 marae, numerous schools, participated in several community events and run training classes in penal institutions. Over 2000 people have been introduced to mau rakau as a result of these activities (CEG 1998a: 63-72). Over the past 15 years, classes in the weaponry school have expanded. The curriculum has been broadened to provide a comprehensive programme in several areas of cultural, social and educational development.

The development of Te Whare Tu Taua as an organisation 
has accelerated over recent times as the knowledge base and the number of participants has expanded and as access to government assistance became more readily available through the advent of CEG. Funding assistance from CEG has allowed the organisation to support two full time positions supporting the development of the organisation's strategic plan and overseeing the management and development of the organisation at an operational level. Part of this work is focused on developing a training manual with components of the manual registered as unit standards on the National Qualifications Framework. Funding support is, however, becoming critical as interest in the programmes run by the organisation increases. Perhaps ways need to be found to allow the organisation to generate a return from the intellectual and cultural capital it is accumulating to offset rising expenditure.

The impact of Te Whare Tu Taua on employment is difficult to quantify. However, the first group of graduates from the programme in 1997 are all employed and of the 13 graduates, 6 have also achieved tertiary qualifications in conjunction with their graduation as Masters of Maori Weaponry. All are fluent in the Maori language, where none were when they commenced the programme. In terms of the larger community, the impact of the programmes run by the organisation is on the level of employability of the individual under instruction. Objectives of the programme focus on restoring identity and self worth, promoting confidence, encouraging self discipline leading to that individual having the ability to achieve in mainstream education and within the workplace. In the absence of these skills, an individual can be perceived to be less likely to obtain meaningful employment. In the long term, the development of Te Whare Tu Taua is closely linked to the wider educational initiatives being undertaken by Hoani Waititi marae.

Hoani Waititi Marae established the first Kura Kaupapa and Wharekura (Kura Kaupapa Secondary School) in New Zealand in response to the lack of teaching institutions offering Maori language based teaching. In a similar manner, the marae has embarked on a project to establish the first Maori polytechnic institution. The low participation rate of Maori at tertiary institutions and the subsequently low proportion of the population achieving tertiary qualifications is the driving force behind the concept.

The development of the Whare Wananga is being undertaken in partnership with Waipareira which sees significant benefits accruing to Maori through ownership and control over their own tertiary educational institution. The local authority for the area, Waitakere City Council, also sees positive results being achieved from the project. In the first instance it will provide the people of the district with their own tertiary institute, a facility which the other three regional local authorities (Auckland City, Manukau City, North Shore City) have enjoyed for many years.

Many of the people the marae hopes will attend the Whare Wananga include people who have already participated in one of the pre employment or Training Opportunity Programme (TOP) courses. ${ }^{8}$ Amongst the most successful pre- employment programmes run by the marae was the Harrahs Casino programme set up in 1995 in conjunction with Nga Herenga Waka, a consultancy firm, to provide Maori with employment opportunities in the, then under development, Sky Tower Casino complex. The programme was developed in consultation with Harrahs Casino management and was supported by CEG. It was based around standard casino requirements but incorporated Maori cultural concepts, such as manaaki tangata (hospitality) into the training. This type of affirmative action approach to employment was also reflected in the construction of the Sky Tower where it has been estimated that, at times, up to 95 per cent of the workers on site were Maori. Of the 700 people trained by Nga Herenga Waka in 1995, 630 had secured employment (CEG 1996b).

These three projects approach the issue of employment generation from quite different perspectives. Te Whare Tu Taua focuses on working with the individual from a culturally based perspective and employment is perceived as an outcome that will be achieved once the individual has developed a strong sense of self worth and self belief. The Whare Wananga project seeks to address a perceived gap in the institutional structure of tertiary education for Maori. Employment opportunities for Maori will be enhanced by increasing the number of Maori with higher educational qualifications in the labour market; creating more role models for Maori across a wider range of occupations. The Harrahs Casino training programme was developed for a specific employment situation but it demonstrates that a partnership approach to developing employment opportunities for marginalised communities can achieve a significant level of success.

A key factor in all three projects was the presence and participation of Dr Pita Sharples. Dr Sharples is an acknowledged leader in the field of education. In respect of these three projects, Dr Sharples initiated Te Whare Tu Taua and occupies the position of Tumu Whakarae (sacerdotal head), he is the principal of Nga Herenga Waka and works closely with Hoani Waititi marae management.

\section{Manaakitia Trust}

Wanganui is the home of the Manaakitia Trust which is a registered Private Training Establishment with New Zealand Qualifications Authority accreditation for the teaching of whakairo (Maori carving). The Trust's commercial enterprise is Ngahere Woodware, specialising in the creation of unique taonga (treasures), restoration of old carvings and undertaking of carving commissions. High profile exposure of this work was ensured when the Trust won the contract in 1997, for the making of the trophies for the World Jetboating Competition. A variety of other important carving commissions have also been undertaken. For example a pou for the Wanganui City Council to present to Wanganui's sister city in Japan and carvings for the whare at Kautarere marae in Opotiki have been commissioned. All traditional Maori musical instruments are also made and wooden $21^{\text {st }}$ birthday keys are frequently ordered by the public (CEG 1998b: 76-79). 
The Trust employs six of its graduates and has a Pou Whakairo (master carver). Around 50 long-term unemployed have trained at Manaakitia, with participants learning traditional skills of carving and weaving. Learning is fostered through the use of a programme called 'Ko wai au' (to know one's self). The programme encourages trainees to research their family history, which in turn serves to instil a sense of belonging and pride in oneself.

The links Manaakitia maintains with local educational institutions is another aspect of the partnership approach to providing training and employment outcomes. Thus a student from the Wanganui Regional Polytechnic supplied the landscape design for the model pa being built by the Trust. Similarly the Trust's joint project with the Wanganui museum to develop a CD Rom on waka, had trainees working with the graphics department of the Polytechnic.

Manaakitia's CTF and other community projects are based on Maori culture and heritage. One such CTF project is the building of an interactive model marae. The model pa project by contrast has 12 workers from the Conservation Corps. ${ }^{7}$ Twelve further workers are on a waiting list because they are keen to be involved with a heritage focused project.

Chief Executive Officer (CEO) of Manaakitia, Ben Poutaka, appointed four years ago, began his job by assisting trustees prepare a strategic plan with the objective of bringing a new focus and direction to Trust's activities. The results achieved by the Trust demonstrate the benefit of this planning process with Poutaka the driving force behind the recent initiatives. Other significant factors that have contributed to the Trust's performance are the support given to the CEO by the Trustees and the support from local whanau and hapu.

\section{Manurewa Community Employment Service}

The Manurewa Community Employment Service operates under the umbrella of the Manukau Peoples Centre to provide a service to members of the centre and other people on low incomes seeking work opportunities, to fill a service gap which was not being filled by either central or local government, and to try and address an anomaly in the labour market where job opportunities geographically co-exist with high levels of unemployment. The intent is to try and ensure that local businesses hire local people.

Since the beginning of this year the service has registered 160 people of whom 75 have moved into casual, contract, part-time or full-time work. These people are long term unemployed, generally registered with WINZ for at least a year with a number being registered over three years. Follow-up support to new employees is also provided by the service (CEG 1998b).

The realisation "that we do make a difference not just to the job seeker but to the whole family", makes Janice Tuhoro, the co-ordinator of the service, fervently push 'spinoffs' as she attempts to persuade employers to take on an additional employee. Her argument is, “ $\ldots$ if a person is working then they will buy within their local community. If we have less unemployment, we have less crime. We use every source we can to try to get people into work. We tell them how they are not just employing one person they are employing a family. Employing one person makes such a difference... good business is about people" (CEG 1998b: 12).

The service was established in the latter part of 1997, with funding provided by CEG, MCC and the Levi Strauss Community Partnership Fund. The involvement of Levi Strauss is significant as they provide the major share of operating funding for the second year of operation. MCC and CEG have also continued their funding support for a further year. As a commercial operation, however, the service is highly marginal as employers will not pay commission fees for the placement of people who are long term unemployed. Nevertheless, the service has demonstrated that success in placing people who are long term unemployed can be achieved even in periods when labour market opportunities are limited.

Since the service operates under the umbrella of the Manukau Peoples Centre, it has a level of credibility in terms of working with unemployed people within the wider community that would not necessarily be the case with another agency. This factor, together with the passion of the service co-ordinator, has served to underpin the success achieved to date.

\section{Conclusion}

This paper provided case study evidence to show that community based training and job creation projects which target specific labour market disadvantaged groups with tailored projects to suit their needs and abilities, are beneficial in generating additional employment and/or enhancing capacity for future employability of participants. On the strength of these and other similar local initiatives (see CEG 1998a), it could even be suggested that it is possible that New Zealand is moving to an alternative development model, as proposed by Alain Lipietz. A core aspect of this model is "the development of the welfare state into a welfare community, with the setting up of a third sector of community work schemes which could be self-managed, contractually bound to end-users, and part of a logic of local development founded on partnership" (Lipietz 1992: 145). While the emergence of an alternative development model is speculation, what this paper does, however, support is that community projects have a pro-active role to play in mitigating the labour market disadvantage of ethnic minorities, who benefit little from opportunities that emerge as a normal consequence of market operations.

The majority of cases presented here, as well as other projects supported by CEG, suggest that the 'green' or 'culture' themes underpin many new generation urban community initiatives. These jobs or programmes require low entry level skills for participants and they are important as self esteem builders espaecially for those whom the formal 
education system has failed. Other than the initiatives profiled, there are others which serve to illustrate the role of the recycling and waste industry and environmental concerns in community job provision (see for example CEG 1997a, 1997b). In the Auckland Region alone there were at least 1,736 employees directly involved in the young and growing recycling industry and these are similar to the numbers in the forestry, fishing and agriculture sector (Waste Not Limited 1998: 4). Similarly, latest Census statistics highlight the overall context of job growth in the cultural sector. People working in arts and culture increased by $31 \%$ between 1991-1996. One fifth of those employed at the time of the Census worked in this sector (Statistics NZ 1998). It is not surprising therefore that many community initiatives are culture based ones. Some initiatives highlighted in this paper also illustrate the importance of recognising the cultural capital and heritage of ethnic minorities in order to both improve employment prospects as well as create employment.

Effective leadership has been inherent in the success of the initiatives examined. Leaders form an integral aspect of the 'market-leading community entrepreneurship' which develops and turns vision into the reality of viable ventures to provide jobs and appropriate training at the local level (de Bruin 1998b). Such leadership may be provided by the more educated, already successful professional who works with his/her community, like Dr Pita Sharples, or the dedication and commitment of those driving or initiating community projects, or group leadership which can come from some members of a runanga or trust or Enterprise Board, as for example with the CEO receiving resolute support from the Board of Trustees of Manaakitia.

A common element in all the initiatives discussed, has been the strong input from the CEG. In this connection, the question that arises is how the outcomes achieved by community initiatives through such input, are 'valued' by the State. These outcomes cannot be measured and valued in terms of representing a fair rate of return on investment as the return is more then just a financial one. Clearly if the State does not appropriately value the outcomes, then funding support will cease. This also begs the question whether the initiatives would have gone ahead without governmental support and the extent to which market failure exists in this arena. While this is a moot question, in many initiatives CEG's intervention has at least accelerated a community process that was already underway. In some instances, such as the Manurewa Community Employment Service, where the project would not have proceeded without CEG, MCC and Levi Strauss support, the partnership approach with governmental input is critical.

\section{Future research}

There is scope for further, more rigorous study and evaluation of active labour market policies at the community level. Cost benefit analysis and a study of the net impact of community projects could be carried out. While the CEG has community impact reports of initiatives, there is need for more in-depth research. Research on individual work histories in order to measure in some way the extent to which programmes which focus on building life skills, lead to measurable employment outcomes, would also be worthwhile.

An examination of Australian labour market programmes indicates the possibility of comparing some community based programmes with those in New Zealand. Research being carried out by the Centre for Aboriginal Economic Policy Research of the Australian National University, identifies efforts to establish a viable aboriginal labour market separate from the mainstream labour market. Comparison of these initiatives with some programmes catering to Maori could be useful. For instance, Redfern, which is an urban, disadvantaged enclave in Sydney, may make a good comparative case study for a similar urban ethnic minority community in New Zealand. The Redfern Aboriginal Corporation has a Community Development Employment Projects Mission Statement which in addition to commercial goals, gives high priority to culturally-based objectives: the strengthening of Aboriginal identity, improving self respect and confidence and the provision of positive role models (Smith 1995). There is broad similarity between these goals and those of several community organisations in New Zealand. Detailed study of Australian community employment schemes such as in Redfern, and New Zealand programmes, to obtain lessons on community based employment generation to help disadvantaged communities in both countries, could be valuable research.

\section{Notes}

1. Caution is advised in taking such aggregate HLFS ethnicity related figures at face value. For example, a paper in these Proceedings: Chapple, S. and Rea, D. 'Disparity between Maori and non-Maori in the Household Labour Force Survey' points out that although the disparity in the labour market outcomes between Maori and non-Maori is greater today than it was in 1985, the outcomes of the 'Mixed Maori' Group are similar to those of the non-Maori population over time. Furthermore, the relatively small number of Pacific group households in the sample for the HLFS contributes to sampling error. Nevertheless it is a fact that HLFS and Census data from 1986-1996, do indicate that there are wide disparities in employment outcomes among ethnic groups.

2. Rising unemployment of the 'other' group is also of concern. See de Bruin 1998a.

3. WTNZ came into being on 1 October 1998. It is a 'onestop-shop' resulting from a reorganisation of the New Zealand Employment Service, Income Support and CEG.

The Otara Ward of the South Auckland City of Manukau is a community of approximately 32,000 people. It is a clearly identifiable ethnic minority community since $78 \%$ of its residents belong to the Maori and Pacific Island ethnic groups.

4. According to the 1996 Census data, 10,179 people in Otara had no educational qualifications, 6,735 were in receipt a benefit (unemployment, domestic purposes, 
sickness benefits and the student allowance), and 2301 people were seeking work.

5. For further information on Enterprise Otara (EO) and its other projects, see EO 1995 and de Bruin 1997.

6. Community Taskforce (CTF) provides work experience for job seekers through projects which are of community benefit. The objective is to improve work skills of participants and thus increase their chances of securing a job. Participation in Community Taskforce (CTF) is for 3 days per week and the sponsor pays participants a minimum weekly allowance $(\$ 21$ from 1 October 1998 , earlier $\$ 20$ ). Allowance costs are reimbursed to the sponsor by WINZ on a monthly basis. Participants also continue to receive any benefit entitlements. After 1 October 1998, CTF initiatives became known as community work projects. As part of the Agreement between the sponsor and WINZ, it is agreed that the work will not displace existing employment opportunities and participants are selected only from eligible job seekers referred by WINZ.

7. Community Broker Organisations (CBOs) are organisations contracted by CEG to find community work and work experience opportunities for unemployed people.

8. TOP Training Opportunity Programmes. The name given to the training programmes purchased by the Education and Training Support Agency (ETSA). This is a government agency funded through Vote Education and charged with the responsibility for purchasing post secondary school training targeted at people with a low level of secondary school academic achievement.

9. Conservation Corps is administered by the Ministry of Youth Affairs. It is a joint community and government programme with a work skill acquisition, conservation and personal development focus for youth. Projects average 21 weeks. Sponsors are government agencies, community organisations, educational institutions and iwi trusts. Government covers overhead costs and the training allowance for participants.

\section{References}

Carroll, P. (1998) Role model for young Maori, New Zealand Herald 20 October: D6.

CEG: Community Employment Group (1998a) Community Impact Report, Unpublished draft.

CEG: Community Employment Group (1998b) New opportunities for jobseekers, Employment Matters $9(9): 1,8$.

CEG: Community Employment Group (1997a) Investing in rubbish, Employment Matters 8(7): 7.

CEG: Community Employment Group (1997b) Marae benefit from centre, Employment Matters 8(2): 11.

CEG: Community Employment Group (1996a) Finding solutions to problems, Employment Matters 7(11): 5.

CEG: Community Employment Group (1996b) Maori staff plentiful at casino, Employment Matters 7 (2): 3 .

de Bruin, A. (1997) From Cultural to Economic Capital: Community Employment Creation in Otara, in Morrison, P.S (ed.) Labour Employment and Work in New Zealand. Proceedings of the Seventh Conference Wellington: Victoria University of Wellington, pp 89-96.

de Bruin, A. (1998a) Asians bearing the brunt of higher unemployment, New Zealand Herald 7 September.

de Bruin, A. (1998b) Entrepreneurship in a new phase of capitalist development, Joumal of Interdisciplinary Economics, 9(3): 185-200.

Enterprise Otara (1995) Enterprise Otara Brochure, Auckland: Enterprise Otara, November.

Lipietz, A. (1992) Towards a New Economic Order, (English Translation), Cambridge: Polity Press.

Manu, C. (1996) Otara Creek Revegetation Project, Draft Plan, Onu Group Consultants for Enterprise Otara, February.

Mare, D. (1995) Examining labour market outcomes for Maori, Labour Market Bulletin, 1995(1): 116-123.

Manukau City Council (1998) Manukau state of the environment report: final draft. Auckland: Manukau City Council, September.

OECD (1993) Partnerships: The key to employment creation Paris: Organisation for Economic Co-operation and Development.

Smith, D. (1995) Culture Work or Welfare Work: Urban Aboriginal CDEP Schemes, Social Policy Research Centre Reports and Proceedings No.122, University of New South Wales.

Statistics NZ (1998) Employment in the Cultural Sector Wellington: Statistics New Zealand.

Waste Not Limited (1998) Survey of Recycling Businesses in the Auckland Region, Auckland: Waste Not Limited.

\section{Authors}

Anne de Bruin is a Senior Lecturer in Economics,

Department of Commerce,

Massey University - Albany Campus

Private Bag 102904, NSMC, Auckland

E-mail: A.M.De Bruin@massey.ac.nz

Grant Power is a Community Employment Adviser,

Work and Income New Zealand:

Community Employment Group,

PO Box 23778, Hunters Corner, Auckland 